\title{
PRAKTYKOWANIE POSTU W ŚWIETLE HISTORIOGRAFII KOŚCIELNEJ IV-V WIEKU ${ }^{1}$
}

Post - dobrowolne wyrzeczenie się wybranych pokarmów, czy też rezygnacja ze spożywania czegokolwiek w określonym czasie, przyjmował w dziejach różnorakie formy. W kulturach archaicznych miał na ogół charakter okazjonalny i wiązał się np. z żałobą czy też z inicjacją ${ }^{2}$. W cywilizacji

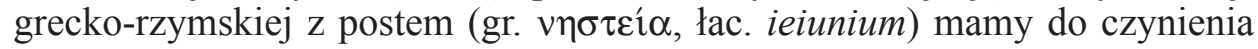
rzadko ${ }^{3}$. W życiu religijnym starożytnych Greków i Rzymian wstrzemięźliwość od pokarmów i napojów nie odgrywała większej roli. Wegetarianizm praktykowany w kręgach filozoficznych nie miał podłoża religijnego czy moralnego, ale jedynie zdrowotne czy higieniczne. Zachęcanie do wstrzemięźliwości w spożywaniu pokarmów przez mędrców miało prowadzić do dobrego życia oraz być wyrazem miłości do filozofii ${ }^{4}$. W przekonaniu ówczesnych w kwestii wyżywienia bogowie nie narzucali im żadnych ograniczeń. Ta sfera była natomiast uregulowana prawem religijnym w judaizmie ${ }^{5}$. Generalnie post związany był tam z żałobą i pokutą (por. Ne 9, 1), praktykowany szczególnie po klęskach spadających na całą społeczność (por. 1Sm 31, 13; Jl 1, 1 - 2, 15). Towarzyszył również prośbom o oddalenie klęski (por. J1 2, 12-17; Jdt 4, 9-13, Dn 9,3), a także modlitwie wstawienniczej i błagalnej (por. 2Sm 12, 16; Sdz 20, 26; Tb 12, 8), przed podjęciem ważnej decyzji czy wypełnieniem trudnej misji (por. Est 4, 16). Post służył przygotowaniu na spotkanie z Bogiem (Wj 34, 28; $1 \mathrm{Krl} \mathrm{19,8),} \mathrm{a} \mathrm{w} \mathrm{końcu} \mathrm{stał} \mathrm{się} \mathrm{również} \mathrm{obrzędem} \mathrm{liturgicznym} \mathrm{(por.}$ Za 8, 19; Kpł 16, 29-34). Tendencje ascetyczne, których wyrazem było m. in. wyłączenie $\mathrm{z}$ jadłospisu wina i mięsa, widoczne były wyraźnie w judeochrześ-

* Dr hab. Sławomir Bralewski, prof. UŁ - profesor nadzwyczajny w Katedrze Historii Bizancjum w Instytucie Historii na Wydziale Filozoficzno-Historycznym Uniwersytetu Łódzkiego; e-mail: sbralewski@o2.pl.

${ }^{1}$ Artykuł został napisany w związku z grantem 2011/01/BHS3/01020.

2 Por. J. Claudian, Le jeûne dans les civilisations ,primitives” et dans les religions du passé, w: Redécouverte du jeûne. Sagesse du corps, ed. P.R. Régamey, Paris 1959, 153-184.

${ }^{3}$ Por. V.E. Grimm, From Feasting to Fasting, the Evolution of a Sin: Attitudes to Food in Late Antiquity, London - New York 1996, 40-43.

${ }^{4}$ Por. tamże, s. 44-59. Zob. Porphyrius, De Abstinentia ab esu animalium I 37-38.

${ }^{5}$ Por. H.A. Brongers, Fasting in Israel in Biblical and Post-Biblical Times, „Oudtestamentische studiën” 20 (1977) 1-21; Grimm, From Feasting to Fasting, s. 28-33; M. Rosik, Post w Biblii, EK XVI 61-62. 
cijaństwie ${ }^{6}$. Chrześcijanie z postu uczynili regularną praktykę. Powoływano się na przykład postaci ze Starego Testamentu, co widać np. w powstałych w IV wieku apokryficznych Konstytucjach Apostolskich. Czytamy w nich:

„Mojżesz i Eliasz także pościli przez czterdzieści dni (por. Wj 34, 28; $1 \mathrm{Krl}$ 19,8 ), a Daniel przez trzy tygodnie nie jadł wybornych potraw ani mięsa, a wino nie dotknęło jego ust (por. Dn 10, 2-3). I błogosławiona Anna, gdy się modliła o Samuela, powiedziała: «Nie piłam wina ani sycery, wylewam tylko duszę moją przed Panem» (1Sm 1, 15). Mieszkańcy Niniwy pościli przez trzy dni i trzy noce (por. Jon $3,4 \mathrm{nn}$ ) i dzięki temu uniknęli niebezpieczeństwa gniewu, a Estera, Mardocheusz (por. Est 4, 15nn) i Judyta (por. Jdt 8,6 ) dzięki postowi uniknęli ataku bezbożnego Holofernesa i Hamana (por. Est 7, 9 - 8,7). Także Dawid rzecze: «Kolana mi się chwieją od postu i ciało moje schnie bez oliwy» (Ps 109(108), 24). I wy poszcząc przedstawiajcie Bogu swe prośby"7.

Przede wszystkim jednak powoływano się na czterdziestodniowy post Jezusa przed rozpoczęciem przez Niego działalności publicznej (por. Mt 4, 2; Łk 4, 2) ${ }^{8}$. W tym kontekście trzeba zauważyć, że w czasach biblijnych post miał charakter praktyki przygotowawczej a nie ascetycznej ${ }^{9}$. Post połączony z modlitwą i jałmużną stał się elementem triady przejętej przez tradycję chrześcijańską ze Starego Testamentu ${ }^{10}$. W dodatku wierni byli do postu zobowiązani, jak świadczy chociażby Didache, najstarszy z zachowanych tekst chrześcijański nienależący, czy kanony przyjmowane na różnych zgromadzeniach biskupów oraz formułowane przez Ojców Kościoła. Dowodzą tego również powstałe w IV wieku Konstytucje Apostolskie, które choć należą do apokryfów, wyrażają tradycję właściwą środowisku antiocheńskiemu, czy powstałe w tym samym wieku związane ze środowiskiem aleksandryjskim kanony Atanazego i Hipolita. W IV wieku, niesłychanie brzemiennym dla dziejów Kościoła, kiedy to chrześcijaństwo z prześladowanej, a potem tolerowanej, stało się religią państwową, narodziła się historiografia kościelna, która szczególnie bujny rozkwit zanotowała w następnym stuleciu. W niniejszym artykule postaram się wyjaśnić, czy Historie kościelne z wieków IV i V, przedstawiając wydarzenia ważne dla dziejów Kościoła, dają także świadectwo praktyce po-

\footnotetext{
${ }^{6}$ Por. J. Daniélou, Teologia judeochrześcijańska, tłum. S. Basista, Kraków 2002, 420-424.

${ }^{7}$ Constitutiones Apostolorum V 20, 15-17, ŹMT 42 [wyd. grecko-polskie, układ i opracowanie A. Baron - H. Pietras, tłum. S. Kalinkowski], Kraków 2007 = SCL 2, 134-135.

${ }^{8}$ Por. Por. J.B. Muddiman, Jesus and Fasting, w: Jesus aux origines de la Christologie, éd. J. Dupont, Gembloux 1975, 283-301; J.N. Suggit, Post, w: Stownik wiedzy biblijnej, red. B.M. Metzger - M.D. Coogan, konsultacja wyd. polskiego W. Chrostowski, Warszawa 1999, 610-611; Rosik, Post w Biblii, s. 62.

${ }^{9}$ Por. J. Wimmer, Fasting in the New Testament: A Study in Biblical Theology, New York 1982, passim; komentarz J. Homerskiego do Ewangelii według św. Mateusza (Pallottinum, Poznań 2004, 113).

${ }^{10}$ Por. T. Špidlik, Duchowość chrześcijańskiego Wschodu, thum. L. Rodziewicz, Kraków 2005, 291.
} 
stu podejmowanej przez ówczesnych oraz czy informacje, jakie podają na ten temat, zgodne są z przekazem wspomnianych dokumentów prawnych.

W swojej Historii kościelnej Euzebiusz z Cezarei cytował Hegezypa, historyka Kościoła z II wieku, wedle którego Jakub, brat Pański, pierwszy biskup chrześcijańskiej wspólnoty w Jerozolimie, nie tylko nie pił wina ani sycery, nie jadł żadnego mięsa, ale jeszcze zrezygnował z kąpieli i namaszczania ciała oliwą, a brzytwa nie dotknęła jego głowy ${ }^{11}$. Chrześcijanie przejęli wiele zwyczajów związanych z postem od Żydów ${ }^{12}$. Łączyli go z uczynkami miłosierdzia i wyrzeczeniem się zła ${ }^{13}$. Pościli w czasie utrapień czy przed wyborem wysłanników i starszych (por. Dz 13, 2-4; 14, 23; 27, 33-36). Dzieje Apostolskie wspominają o trzydniowym poście Pawła z Tarsu nim został ochrzczony (por. Dz 9, 9). Zwyczaj poszczenia przed chrztem katechumenów znany był w Kościele od najdawniejszych czasów, jak dowodzą tego świadectwa Justyna $^{14}$, Tertuliana ${ }^{15}$ czy Didache ${ }^{16}$. Pościł wówczas cały Kościół lokalny. Chrztu udzielano zazwyczaj w Wielkanoc, toteż najprawdopodobniej przedchrzcielny post stał się pierwowzorem Wielkiego Postu ${ }^{17}$. Niemniej przez pierwsze dwa wieki post przed Wielkanocą trwał na ogół dwa dni, w Wielki Piątek i Wielką Sobotę, a w wieku III przez okres Wielkiego Tygodnia ${ }^{18}$. Tak więc dopiero od IV w. zasadniczym czasem praktykowania wstrzemięźliwości pokarmowej dla chrześcijan stał się okres czterdziestodniowego postu, który poprzedzał święta Zmartwychwstania Pańskiego, a dodatkowo w każdym tygodniu środa i piątek ${ }^{19}$. Nieprzestrzeganie nakazanego postu było wykroczeniem przeciw prawu i nieposłuszeństwem Bogu, jak ujmował to 20. kanon Hipolita ${ }^{20}$. Euzebiusz z Cezarei wskazywał, że chrześcijanie zwłaszcza w okresie męki Pańskiej, oddają się postom, czuwaniom i rozważaniu słowa Bożego ${ }^{21}$. Sokrates

${ }^{11}$ Por. Eusebius Caesariensis, HE II 23, 5.

${ }^{12}$ Por. Rosik, Post w Biblii, s. 62.

${ }^{13}$ Por. J. Misiurek, Post w teologii katolickiej, EK XVI 63.

${ }^{14}$ Por. Iustinus, Apologia I 61, 2-3.

${ }^{15}$ Por. Tertullianus, De baptismo 20, 1, ed. J.G.Ph. Borleffs, CCL 1, Turnholti 1954, 294.

${ }^{16}$ Por. Didache VII 4.

${ }^{17}$ Por. Suggit, Post, s. 611; E. Ferguson, Baptism in the Early Church. History, Theology, and Liturgy in the First Five Centuries, Cambridge (Mi.) 2009, passim; P. Mayendorff, Wschodnia teologia liturgiczna, w: Duchowość chrześcijańska. Poczatki do XII w., red. B. McGinn - J. Meyendorff - J. Leclercq, tłum. P. Blumczyński - S. Patlewicz, Kraków 2010, 357. Zdaniem Josepha Patricha (Saba przywódca monastycyzmu palestyńskiego, t. 1, tłum. K. Twardowska, Tyniec 2011, 480) post poprzedzający Wielkanoc w ciągu trzech pierwszych wieków nie był w ogóle praktykowany.

${ }^{18}$ Por. komentarz L. Angliviel de la Beaumelle - G. Sabbah w: Sozomène, Histoire ecclésiastique, Livres VII-IX, SCh 516, Paris 2008, 171, nota 5.

${ }^{19}$ Por. Constitutiones Apostolorum VIII 47, 69 (= Canones Apostolorum 69), SCL 2, s. 289; Canones Hippolyti can. 20, ŹMT 49 [wyd. arabsko-polskie, układ i opracowanie A. Baron - H. Pietras, thum. J. Szymańczyk], Kraków 2009 = SCL 3, 190.

${ }^{20}$ Por. Canones Hippolyti can. 20, SCL 3, 190. Także Kanony Apostolskie (can. 69) przewidywały surowe kary dla duchownych i świeckich za nieprzestrzeganie postu we wspomnianych dniach.

${ }^{21}$ Por. Eusebius, HE II 17, 21. 
z Konstantynopola podkreślał jednak, że post poprzedzający Wielkanoc zachowywany był w każdym Kościele inaczej. Rozróżniał trzy zasadnicze zwyczaje wiernych w tej kwestii. Jak zauważył historyk, pościli oni trzy, sześć lub siedem tygodni. Do pierwszej grupy zaliczył wiernych Kościoła rzymskiego, którzy mieli odbywać post bez przerwy przez trzy tygodnie z wyjątkiem Wielkiej Soboty i Niedzieli Zmartwychwstania ${ }^{22}$. Nieco dalej jednak sam sobie zaprzeczył, stwierdzając, że w Rzymie poszczą w każdą sobotę ${ }^{23}$. List papieża Innocentego I do Decentiusa dowodzi, że druga informacja podana przez Sokratesa była prawdziwa ${ }^{24}$. Do drugiej grupy Sokrates zaliczył wiernych z Illyricum, całej Hellady oraz Aleksandrii, podkreślając, że i oni nazywają swój post czterdziestodniowym ${ }^{25}$. Trzecią grupę wiernych $\mathrm{w}$ jego relacji stanowili ci, którzy w ciągu siedmiu tygodni pościli jedynie przez trzy z nich, ale również nazywali swój post czterdziestodniowym ${ }^{26}$. Sokrates zwrócił uwagę, że nazwa ta nijak się ma do rzeczywistej liczby dni postu odbywanego przez różne wspólnoty chrześcijan przed świętem Wielkanocy ${ }^{27}$. Podobnie pisał Hermiasz Sozomen, wskazując z jednej strony, że czterdziestodniowy post był czasem, w którym pościł ogół wiernych, z drugiej jednak, że w poszczególnych rejonach Imperium Romanum długość jego trwania nie była jednakowa. Sozomen, podobnie do Sokratesa, dla zobrazowania swego twierdzenia, prawdopodobnie opierając się na tekście swego poprzednika, wskazywał na różny czas trwania postu przed Wielkanocą w zależności od lokalnego Kościoła. Historyk sprostował jednak informację podaną przez Sokratesa a dotyczącą Rzymu i mającego się tam odbywać trzytygodniowego postu. Napisał bowiem, że na Zachodzie - a więc także w Rzymie - wraz z Illyricum, a także w całej Libii i Egipcie oraz w Palestynie praktykowano go przez sześć tygodni ${ }^{28}$. Niektórzy badacze thumaczą wskazaną rozbieżność rozłożeniem trzytygodniowego postu w czasie sześciu tygodni. W ten sposób w Rzymie wierni mieliby podejmować post $\mathrm{w}$ pierwszym, czwartym i szóstym tygodniu przypadającym przed Wielkanocą $^{29}$. Co prawda o podobnej praktyce mającej miejsce w niektórych Kościołach pisał też Sozomen ${ }^{30}$, ale Sokrates podkreślał, że w ciągu tych trzech

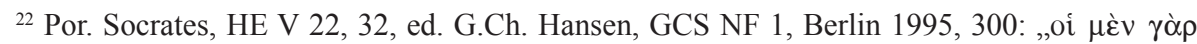

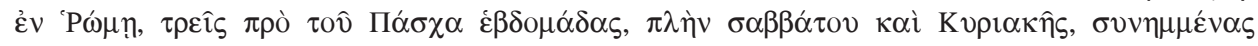

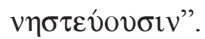

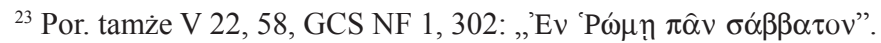

${ }^{24}$ Por. Innocentius I, Epistula ad Decentium 4, PL 56, 516A.

${ }^{25}$ Por. Socrates, HE V 22, 33. O poście sześciotygodniowym pisał też Euzebiusz z Cezarei (De solemnitate Paschali 5, PG 24, 700B-C), Atanazy z Aleksandrii wielokrotnie wspominał o poście czterdziestodniowym (Epistulae festales 2, 8; 3, 5-6; 6, 12-13; 7, 11; 10, 12; 11, 15; 12, 1; 13,8; 19, 9-10).

${ }^{26}$ Por. Socrates, HE V 22, 34.

${ }^{27}$ Por. tamże V 22, 35.

${ }^{28}$ Por. Sozomenus, HE VII 19, 7.

${ }^{29}$ Por. Patrich, Saba przywódca monastycyzmu palestyńskiego, t. 1, s. 481-482.

${ }^{30}$ Por. Sozomenus, HE VII 19, 7, ed. J. Bidez - G.Ch. Hansen, GCS NF 4, Berlin 1995, 331:

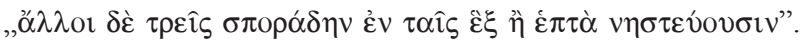


tygodni poszczono w Rzymie bez przerwy $(\sigma v \vee \eta \mu \mu \varepsilon ́ v \alpha \varsigma)^{31}$. Jean Gaudemet uważał jednak, że początkowo w IV w. post w Rzymie trwał trzy tygodnie z wyjątkiem sobót i niedziel, a dopiero później przedłużono go do sześciu tygodni ${ }^{32}$. Wedle francuskiego badacza pierwsze świadectwo sześciotygodniowego postu na Zachodzie pochodzi z roku 384, a więc zapewne z Itinerarium Egerii, gdzie jest mowa o czterdziestodniowym poście przed Wielkanocą ${ }^{33}$. Na ogół uczeni uważają, że Kościół rzymski pościł sześć tygodni, wliczając $\mathrm{w}$ to także okres Wielkiego Tygodnia, jednak z wyłączeniem niedziel, co dawało w sumie $36 \mathrm{dni}^{34}$.

Zwraca uwagę, że wśród obszarów, na których wierni pościli sześć tygodni, Sozomen wymienił Palestynę $e^{35}$, czego wcześniej nie zrobił Sokrates. Niewątpliwie wynikało to ze związków Sozomena z tym obszarem, wszak wywodził się z okolic Gazy, leżącej w Palestynie, stąd wszelkie kwestie związane z tamtejszym Kościołem były mu bliskie. Sozomen uzupełnił też informacje podane przez Sokratesa, wskazując, że w Konstantynopolu i leżących wokół niego prowincjach, aż po Fenicję (a więc historyk brał tu pod uwagę także Antiochię), post przed Wielkanocą trwał siedem tygodni ${ }^{36}$. Wedle Sozomena byli też i tacy, którzy pościli wówczas trzy tygodnie, czy tylko dwa, jak montaniści ${ }^{37}$. O tym, że Montanus ustanawiał własne przepisy postne wspominał Euzebiusz z Cezarei, cytując fragment dzieła bliżej nieznanego Apoloniusza $^{38}$. Sokrates i Sozomen pisali swe Historie kościelne w V w., jak zatem widać jeszcze wówczas praktyka postu poprzedzającego Wielkanoc nie była w Kościele uregulowana. Trzeba jednak pamiętać, że sobór w Nicei w roku $325 \mathrm{w} 5$. kanonie wspominał o czterdziestodniowym poście $\mathrm{w}$ odniesieniu do wszystkich Kościołów lokalnych ${ }^{39}$ i o tym, że jest to najwcześniejsze świadectwo postu określanego tym mianem.

${ }^{31}$ Socrates, HE V 22, 32, GCS NF 1, 300.

${ }^{32}$ Por. J. Gaudemet, L'Église dans l'Empire romain (IV-V siècles), Paris 1958, 659.

${ }^{33}$ Por. Itinerarium Egeriae 27, 1.

${ }^{34}$ Por. L. Duchesne, Origines du culte chrétien: étude sur la liturgie latine avant Charlemange, Paris 1889, 241-247; E. Vacandard, Carême, DThC II 1724-1750; komentarz L. Angliviel de la Beaumelle - G. Sabbah w: Sozomène, Histoire ecclésiastique, SCh 516, 171, nota 5.

${ }^{35}$ Według świadectwa Egerii (Itinerarium Egeriae 27, 1) kilkadziesiąt lat poprzedzającego relację Sozomena, post przed Paschą w Kościele jerozolimskim trwał osiem tygodni z wyłączeniem niedziel i sobót z wyjątkiem Wielkiej Soboty. Nazywano go czterdziestnicą, gdyż trwał równo 41 dni. O ośmiotygodniowym poście wspominał też Doroteusz z Gazy (Doctrinae universae 15, tłum. M. Borkowska, w: Doroteusz z Gazy, Pisma ascetyczne, ŹM 51, Tyniec 2010, 230-231) żyjący w VI w.

${ }^{36}$ Por. Sozomenus, HE VII 19, 7. Niemniej Jan Chryzostom (In epistulam ad Hebraeos hom. 17, 4, PG 63, 131-132) jako biskup Konstantynopola wspominał także o mającym tam miejsce poście czterdziestodniowym.

${ }^{37}$ Por. Sozomenus, HE VII 19, 7. Montaniści tworzyli sektę religijną, nazywaną też herezją Frygijczyków, od miejsca powstania ok. 150 roku. Od IV wieku ruch nosił nazwę od imienia swego najwybitniejszego przedstawiciela Montanusa.

${ }^{38}$ Por. Eusebius, HE V 18, 2.

${ }^{39}$ Por. Concilium Nicaenum (325) can. 5, thum. T. Wnętrzak, DSP 1, 31. 
Konstytucje Apostolskie nakazywały przestrzeganie:

„,czterdziestodniowego Postu na pamiątkę sposobu życia i nauczania Pana. Ten post winien się skończyć przed postem paschalnym, i trwać od drugiego dnia do dnia Przygotowania. Po upływie tych dni przerwiecie post i rozpoczniecie święty tydzień Paschy"40.

Tak więc $\mathrm{w}$ Kościele antiocheńskim post czterdziestodniowy zaczynał się w drugim dniu po szabacie, a więc w poniedziałek, gdyż „w tym dniu zaczęli spiskować przeciwko Panu"41 i trwał do dnia Przygotowania ( $\pi \alpha \rho \alpha \sigma \kappa \varepsilon v \eta ́)$, a więc do piątku i tak aż do tygodnia Paschy. Zwracam uwagę, iż nie było mowy o poście w czasie tych czterdziestu dni w soboty i w niedziele.

Jak się wydaje, praktykowano wtedy post surowy. Według relacji Sozomena $^{42}$ w rodzinie Spirydona, biskupa Tremituntu na Cyprze, słynącego co prawda ze świętości, spędzano dni na czczo, jadając jedynie w wyznaczonym dniu ${ }^{43}$. W pozostałe dni w domu nie było chleba ani nawet mąki, być może dlatego, by uniknąć pokusy. Historyk tłumaczy to brakiem potrzeby zaopatrywania spiżarni, skoro rodzina nie spożywała żadnych pokarmów. Kiedy jednak w ich domu pojawił się niespodziewanie, na co wskazują okoliczności, gość będący w podróży, wyglądający w dodatku na bardzo utrudzonego, Spirydon nie zawahał się polecić przygotowanie mu posiłku ze smażonej wieprzowiny, której marynat znajdował się w domu. Najpierw jednak pomodlił się i poprosił Boga o przebaczenie. Odczuwał więc dyskomfort, łamiąc post. Następnie, co ciekawe, razem z gościem zasiadł do stołu i pierwszy przystąpił do jedzenia, zachęcając go do spożycia mięsnej potrawy. Kiedy ten się wzdragał, thumacząc, że jest chrześcijaninem, miał rozwiać jego wątpliwości stwierdzeniem, że tym bardziej nie powinien się wzbraniać „bo dla czystych wszystko jest czyste, jak to objawiło Słowo Boże (por. Tt 1, 15)"'44. Widać dla Spirydona prawo gościnności i obowiązek nakarmienia przybysza więcej znaczył niż nakaz wstrzemięźliwości od pokarmów w Wielkim Poście. Opór przybyłego i otoczka sensacji, w którą ubrał swą opowieść historyk, zdaje się sugerować, że opisane zdarzenie miało charakter wyjątkowy, przynajmniej jeśli chodzi o spożywanie wieprzowiny w czasie czterdziestodniowego postu ${ }^{45}$.

${ }^{40}$ Constitutiones Apostolorum XIII 3-4, SCL 2, 122.

${ }^{41}$ Tamże XIV 1, SCL 2, 122.

${ }^{42}$ Por. Sozomenus, HE I 11, 10-11.

${ }^{43}$ Egeria (Itinerarium Egeriae 28, 1-2) wspominała o niezwykle surowym poście, jaki przed Wielkanocą obowiązywał w Palestynie, gdzie wierni pościli przez cały tydzień, spożywając jeden posiłek w niedzielę po mszy świętej, a następny dopiero w kolejną niedzielę. Ewentualnie spożywali $\mathrm{w}$ tygodniu dwa posiłki w sobotę rano i w niedzielę przed południem.

${ }^{44}$ Sozomenus, HE I 11, 11, GCS NF 4, 24, thum. S. Kazikowski: Hermiasz Sozomen, Historia Kościoła, Warszawa 1989, 53.

${ }^{45}$ Sławny mnich z Tebaidy, Apollos (IV w.) uznawał łamanie postu za zdradę Zbawiciela i krzyżowanie Go. W sytuacji, kiedy w dzień postu przyszedłby brat w potrzebie, Apollos zalecał przygo- 
Konstytucje Apostolskie wyraźnie wyróżniały post w tygodniu Paschy. Odróżnienie czterdziestodniowego postu od postu przypadającego w tygodniu Paschy było właściwe dla Antiochii i okolicznych Kościołów ${ }^{46}$, podczas gdy Kościoły w Rzymie i na Zachodzie oraz w Aleksandrii i Jerozolimie wliczały post z Wielkiego Tygodnia do postu czterdziestodniowego ${ }^{47}$. Według Konstytucji sam Chrystus nakazał pościć w tygodniu Paschy przez sześć dni „ze względu na bezbożność i niesprawiedliwość Żydów”48. W innym miejscu Konstytucje Apostolskie nakazywały w dniach Paschy post od poniedziałku do piątku i soboty, a więc także przez sześć dni. W tym czasie wierni spożywać mieli tylko chleb i sól z jarzynami, a pić tylko wodę, powstrzymując się zarówno od wina, jak i od mięsa, ,ponieważ są to dni smutku, a nie radości”49. Podobnie 22. kanon Hipolita przewidywał na tydzień Paschalny jako właściwy pokarm jedynie chleb, sól i wodę ${ }^{50}$. Wedle Konstytucji Apostolskich w Wielkim Tygodniu:

„Jeśli komuś starczy sił, niechaj pości przez cały piątek i sobotę nic nie jedząc aż do nocnego piania koguta. Kto jednak nie ma siły pościć przez dwa dni, niech zachowa post przynajmniej w sobotę. Pan bowiem mówi odnośnie do siebie: «kiedy zabiorą im pana młodego, wtedy, w owe dni będą pościli» (Łk 5, 35; por. Mt 9, 15; Mk 2, 20)"s51.

Jak się zatem wydaje, zarówno w piątek jak i sobotę paschalną obowiązywał post całkowity.

Konstytucje Apostolskie w tygodniu paschalnym od poniedziałku do czwartku zalecały post do wieczora, zezwalając na zjedzenie posiłku dopiero o godzinie 21. Dopuszczały jednak możliwość złagodzenia postu „wedle swych sił" ${ }^{52}$. Zalecano też przerwanie postu w czwartek wieczorem aż do piania koguta, a więc do wczesnych godzin porannych w piątek ${ }^{53}$. Przeciwko łamaniu postu w Wielki Czwartek występował 50. kanon synodu w Laodycei z końca IV wieku. Przerwanie postu w czwartek ostatniego tygodnia uważali zgromadzeni tam biskupi za bezczeszczenie całego czterdziestodniowego postu. Uważali ponadto, że przez cały okres Wielkiego Tygodnia należy pościć,

tować dla niego samego stół. Jeśliby jednak przybysz odmówił spożycia posiłku, zdaniem mnicha nie należało go do jedzenia zmuszać (Historia monachorum in Aegypto VIII 58).

${ }^{46}$ Joseph Patrich (Saba przywódca monastycyzmu palestyńskiego, t. 1, s. 481) uważa, że także dla Kościoła w Aleksandrii.

${ }^{47}$ Por. komentarz L. Angliviel de la Beaumelle - G. Sabbah w: Sozomène, Histoire ecclésiastique, SCh 516, 171, nota 5.

${ }^{48}$ Constitutiones Apostolorum V 14, 20, SCL 2, 126.

${ }^{49}$ Tamże V 18, SCL 2, 129-130.

${ }^{50}$ Por. Canones Hippolyti can 22, SCL 3, 191.

${ }^{51}$ Constitutiones Apostolorum V 18, 2, SCL 2, 130.

${ }^{52}$ Tamże V 19, SCL 2, 130.

${ }^{53}$ Por. tamże. 


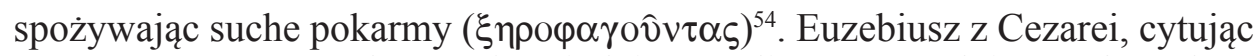
Ireneusza z Lyonu, wskazywał, że jedni uważali, że w tygodniu Paschy należy pościć przez jeden dzień, inni - że przez dwa, a jeszcze inni - że dłużej5 ${ }^{55}$. Podobnie wedle Dionizego Aleksandryjskiego byli tacy, którzy pościli dwa, trzy, cztery czy sześć dni, ale i tacy, którzy nie pościli wcale ${ }^{56}$.

Sozomen wskazywał, że szczególnym dniem wstrzemięźliwości pokarmowej był Dzień Przygotowania (Wielki Piątek), ,kiedy to społeczność wiernych z wielką pobożnością przestrzega postu dla upamiętnienia zbawczej Męki"57. Zdarzało się jednak, że nie wszyscy obchodzili Święta Wielkanocne w tym samym terminie, a wówczas także post przypisany do tygodnia Paschy odbywali w innym czasie. Mimo, że kwestię tę uregulował już sobór w Nicei, o czym informował list zgromadzonych tam biskupów, przekazany m.in. przez Sokratesa z Konstantynopola i Teodoreta z Cyru ${ }^{58}$. Z historyków kościelnych o ujednoliceniu obchodów Świąt Wielkanocnych pisał też Rufin z Akwilei ${ }^{59}$ czy Sozomen ${ }^{60}$. Na ogromne zamieszanie, jakie powodowały wśród wiernych różnorodne terminy obchodzenia Wielkanocy, kiedy to jedni chrześcijanie pościli, a inni w tym czasie świętowali, zwracał uwagę list cesarza Konstantyna skierowany do Kościołów po soborze w Nicei, cytowany w Historiach kościelnych Sokratesa z Konstantynopola i Teodoreta z Cyru ${ }^{61}$. W późniejszym czasie poszczenia i świętowania z Żydami zabraniały też Konstytucje Apostolskie ${ }^{62}$. Sozomen zilustrował w swym dziele, do jakich absurdów prowadził brak jedności w tej kwestii, wskazując na przypadek nowacjanina Sabattiosa ${ }^{63}$, który obchodził Wielkanoc dwa razy. Najpierw świętował ją prywatnie razem z Paschą żydowską i dlatego także ,pościł wcześniej, niż to było we zwyczaju" ${ }^{64}$. Potem jednak w Wielką Sobotę trwał z innymi na modlitwie, a następnego dnia „,razem ze wszystkimi uczestniczył w nabożeństwie i przystępował do świętych tajemnic ołtarza", co oburzało nowacjan i doprowadziło wśród nich do rozłamu.

Opisując postępowanie Sabbatiosa, Sozomen nadmienił, iż ten w Wielką Sobotę „od wieczora do tej godziny, co trzeba”, trwał na czuwaniu i stosow-

${ }^{54}$ Concilium Laodicense (koniec IV w.) can. 50, ŹMT 52 [wyd. grecko-polskie, układ i opracowanie A. Baron - H. Pietras, tłum. S. Kalinkowski], Kraków 2010 = SCL 4, 118.

${ }^{55}$ Por. Eusebius, HE V 24, 12.

${ }^{56}$ Por. Dionisius Alexandrinus, Epistula ad Basilidem 1, thum. S. Kalinkowski, SCL 3, 3.

${ }^{57}$ Sozomenus, HE VII 19, thum. Kazikowski, s. 498.

${ }^{58}$ Por. Theodoretus Cyrensis, HE I 11 (Epistula Nicaeni concilii ad Aegyptios); Socrates, HE I 9, 1.

${ }^{59}$ Por. Rufinus, HE I 6.

${ }^{60}$ Por. Sozomenus, HE I 21, 6.

${ }^{61}$ Por. Socrates, HE I 9, 40; Theodoretus, HE I 10, 9.

${ }^{62}$ Por. Constitutiones Apostolorum VIII 70, SCL 2, 290.

${ }^{63}$ Por. Sozomenus, HE VII 18.

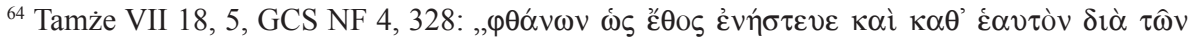

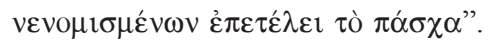


nych modlitwach ${ }^{65}$. Uczestniczył zatem w ostatnich godzinach postu przed świętowaniem zmartwychwstania Chrystusa. Historyk nie określił jednak dokładnie czasu, do którego ów post i czuwanie trwały. Wydaje się, że zrobił to świadomie, bo i w tym przypadku nie było wśród chrześcijan jednomyślności. Euzebiusz z Cezarei wspominał już, że Kościoły całej Azji przerywały post czternastego dnia księżyca, kiedy ich zdaniem należało obchodzić święto Paschy bez względu na to, jaki wówczas przypadał dzień tygodnia. Pozostałe Kościoły całego świata natomiast miały stać na stanowisku, że nie godzi się przerwać postu w żaden inny dzień, jak tylko w dzień zmartwychwstania Chrystusa przypadający w niedzielę ${ }^{66}$. Z listu Dionizego Aleksandryjskiego skierowanego do Bazylidesa ${ }^{67}$, biskupa Pentapolis w Libii, wynika w dodatku, że niektórzy kończyli ów post w sobotę wieczorem, inni przed północą, jeszcze inni wraz z pianiem koguta, a byli też tacy, którzy czekali aż do czwartej straży nocnej, czyli wczesnych godzin porannych. Owa rozbieżność związana była z przekonaniem, że umartwienie w postaci postu powinno trwać do chwili zmartwychwstania Chrystusa. Jednak żadne świadectwo ewangelistów nie precyzowało, kiedy ten moment nastąpił. Tak więc Dionizy wskazywał, że ustalenie dokładnej godziny zmartwychwstania Chrystusa nie było możliwe.

Osoby uchodzące za pobożne pościły bardzo często, ale poszczono przede wszystkim w określone dni tygodnia. Filostorgiusz, autor eunomiańskiej $\mathrm{Hi}$ storii kościelnej, wskazywał, że były to: środa i piątek ${ }^{68}$. W relacji Sokratesa z Konstantynopola cesarz Teodozjusz II uprawiał posty bardzo często, ale szczególnie upodobał sobie w tym celu środy i piątki ${ }^{69}$. Jak podał Sokrates „,robił to ze szczerej chęci ścisłego przestrzegania przepisów religii chrześcijańskiej"70. Chciał zatem wypełniać nakazy prawa kościelnego. W kanonie 15. sformułowanym na podstawie dzieł Piotra, biskupa Aleksandrii (300-311), męczennik ów również wspominał o nakazanym, zgodnie z tradycją, poście w środy i piątki. W środę, gdyż tego dnia Żydzi mieli podjąć decyzję o wydaniu Chrystusa, a w piątek na pamiątkę Jego męki ${ }^{71}$. Podobną argumentacją posługiwały się Konstytucje Apostolskie, które zalecały post albo przez pięć dni $\mathrm{w}$ tygodniu, albo w czwartym dniu oraz $\mathrm{w}$ dniu przygotowania, a więc

${ }^{65}$ Tamże, GCS NF 4, 328: „,

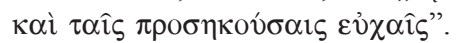

${ }^{66}$ Por. Eusebius, HE V 23, 1-2.

${ }^{67}$ Por. Dionisius Alexandrinus, Epistula ad Basilidem, SCL 3, 1-5.

${ }^{68}$ Por. Philostorgius, HE 1012.

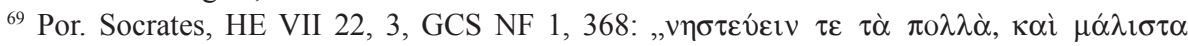

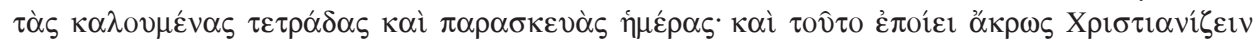

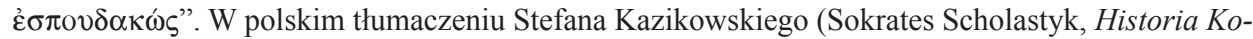
ścioła, Warszawa 1986, 525) jest mowa o postach w czwartki i piątki. W pierwszym przypadku chodzi tu jednak o czwarty dzień tygodnia, a więc o środę (licząc od niedzieli), a nie o czwartek.

${ }^{70}$ Socrates, HE VII 22, 3, GCS NF 1, 368, thum. Kazikowski, s. 525.

${ }^{71}$ Por. Petrus Alexandrinus can. 15, thum. S. Kalinkowski, SCL 3, 22. 
podobnie w środę i piątek ${ }^{72}$. W te dni nakazać post miał sam Chrystus. W środę - ,z powodu zdrady"73, gdyż w ten dzień „rozpoczął się proces przeciw Panu i wtedy też Judasz obiecał, że Go wyda za pieniądze"74 (w innym miejscu w Konstytucjach Apostolskich czytamy, iż w środę oprawcy Chrystusa „postanowili uśmiercić Go na krzyżu”75), w piątek zaś - „ponieważ tego dnia Pan poniósł mękę na krzyżu pod Poncjuszem Piłatem"76. W te same dni post zalecała Didache ${ }^{77}$. Wedle Konstytucji Apostolskich to, co zaoszczędzono poszcząc w te dni, należało oddać ubogim ${ }^{78}$.

W relacji Filostorgiusza w środy i w piątki post nie ograniczał się jedynie do abstynencji od mięsa, ale $\mathrm{w}$ te dni aż do wieczora nie można było nawet dotknąć żywności ${ }^{79}$, czego wymagać miały kanony kościelne. W świetle 13. kanonu synodu w Artsalth (po 373 roku) nakazany w te dni post dotyczył jednak wstrzemięźliwości od mięsa ${ }^{80}$. W relacji Sokratesa z Konstantynopola niektórzy kończyli post nie wieczorem, ale o 9 godzinie dnia, a zatem około 15 godziny naszego czasu ${ }^{81}$.

Nie we wszystkie dni tygodnia można było podejmować post. Didache $e^{82}$ i Konstytucje Apostolskie ${ }^{83}$ przestrzegały przed obłudnikami, którzy poszczą $\mathrm{w}$ drugim i piątym dniu tygodnia, a więc w poniedziałek i czwartek ${ }^{84}$. Z relacji Sokratesa i Sozomena wynika także, że chrześcijanom nie wypadało pościć w niedzielę. Obydwaj wskazywali na przypadek Eustacjusza, biskupa Sebasty w Armenii, który został potępiony na synodzie w Gangrze w Paflagonii za naruszanie przepisów kościelnych ${ }^{85}$. Negować miał również te dotyczące postu. Namawiał bowiem, aby ,zerwać z przestrzeganiem postów nakazanych przez Kościół, a pościć w dni niedzielne" ${ }^{" 86}$. Konstytucje Apostolskie zakazywały postu zarówno w niedzielę, jak i w sobotę:

${ }^{72}$ Por. Constitutiones Apostolorum VII 23, SCL 2, 186-187.

${ }^{73}$ Tamże V 14, 20, SCL 2, 126.

${ }^{74}$ Tamże VII 23, SCL 2, 187.

${ }^{75}$ Tamże V 14, SCL 2, 122.

${ }^{76}$ Tamże VII 23, SCL 2, 187.

${ }^{77}$ Por. Didache VIII 2.

${ }^{78}$ Por. Constitutiones Apostolorum V 20, 18, SCL 2, 135.

${ }^{79}$ Por. Philostorgius, HE X 12.

${ }^{80}$ Por. Concilium in Artsalth (po 373) can. 13, ŹMT 37, [wyd. francusko-polskie, układ i opracowanie A. Baron - H. Pietras, tłum. A. Baron], Kraków 2006 = SCL 1, 279.

${ }^{81}$ Por. Socrates, HE V 22.

${ }^{82}$ Por. Didache VIII 1.

${ }^{83}$ Por. Constitutiones Apostolorum VII 23, SCL 2, 186.

${ }^{84}$ Post w poniedziałki i czwartki należał do praktyki żydowskiej; por. Rosik, Post $w$ Biblii, s. 62; Misiurek, Post w teologii katolickiej, s. 63.

${ }^{85}$ Por. V. Desprez, Początki monastycyzmu, thum. J. Dembska, t. 2, ŹM 22, Kraków 1999, s. 13-15.

${ }^{86}$ Socrates, HE II 43, 5, GCS NF 1, 180, thum. Kazikowski, s. 259. W relacji Sozomena (HE III 14) niektórzy oskarżali o to Eustacjusza, inni jego uczniów. Post w niedzielę praktykowali także pryscylianie; zob. Desprez, Poczatki monastycyzmu, t. 1, ŹM 21, Kraków 1999, 306-307. 
„W szabat jednak i w Dzień Pański świętujcie, bo pierwszy jest wspomnieniem aktu stworzenia, a drugi pamiątką zmartwychwstania" ${ }^{87}$.

Spośród wszystkich sobót post był nakazany jedynie w Wielką Sobotę.

„W jeden tylko szabat w całym roku zachowajcie post, mianowicie w dniu Grobu Pańskiego, w którym należy pościć, a nie świętować. Gdy Stwórca przebywa pod ziemią, ważniejszy jest smutek nad Nim niż radość ze stworzenia, bo Stwórca z natury swej i godności ważniejszy jest niż stworzenie" ${ }^{" 88}$.

\section{Wedle Konstytucji Apostolskich}

„winien grzechu będzie ten, kto pości w dniu Pańskim, który jest dniem zmartwychwstania, albo kto smuci się w dniu Pięćdziesiątnicy lub w jakiekolwiek święto Pana; w te dni trzeba się radować, a nie smucić" $" 89$.

Kanon 18. synodu w Gangrze z roku 340 nakładał anatemę na każdego, kto „powodując się rzekomą ascezą pościł w niedzielę" ${ }^{90}$. Post w niedzielę synod ten uznał za profanację tego wolnego dnia ${ }^{91}$. Również synod w Saragossie z roku 380 (kanon 2.) zakazywał postu w niedzielę czy to ,z powodu czasu [okresu liturgicznego], namowy lub zabobonu (superstitionis)" ${ }^{\prime 92}$. Jeśli w wigilię święta Objawienia, w którą wierni zobowiązani byli do postu, wypadła niedziela, Teofil, biskup Aleksandrii, zalecał zjedzenie kilku daktyli, aby zadość uczynić zakazowi postu w dzień Pański, a przez resztę dnia zrezygnować ze spożywania pokarmów, aż do wieczornej eucharystii ${ }^{93}$. W podobnym duchu rzecz rozstrzygał Tymoteusz Aleksandryjski, wedle którego post zostaje zniesiony przez obmycie wodą po porannej eucharystii, ale potem ponownie zachowywany przez nieprzyjmowanie żadnego pokarmu poza wodą. Tak więc, jak tłumaczył Tymoteusz, z jednej strony post był zniesiony ze względu na niedzielę, a z drugiej zachowywany zgodnie z tradycją związaną ze świętem Objawienia $^{94}$.

Co prawda autorzy Historii kościelnych o tym nie wspominają, ale - jak wynika ze źródeł prawnych - post nakazany był przed niektórymi świętami kościelnymi, tak jak było to w przypadku wspomnianego już święta Objawienia Pańskiego, kiedy w jego wigilię nie przyjmowano żadnego pokarmu poza wodą 95 . O poście przed świętem Objawienia wspominali biskupi Alek-

\footnotetext{
${ }^{87}$ Constitutiones Apostolorum VII 23, 3, SCL 2, 187.

${ }^{88}$ Tamże VII 23, 4, SCL 1, 187. Por. tamże V 20, SCL 2, 126.

${ }^{89}$ Tamże V 20, 19, SCL 2, 135.

${ }^{90}$ Concilium Gangrense (ok. 340) can. 18, SCL 1, 128.

${ }^{91}$ Por. Concilium Gangrense (ok. 340), Epistula synodica 10, SCL 1, 124.

${ }^{92}$ Concilium Caesaraugustanum (380) can. 2, SCL 1, 293.

${ }^{93}$ Por. Theophilus Alexandrinus can. 1, SCL 3, 98.

${ }^{94}$ Por. Timotheus Alexandrinus, Responsa canonica 23, SCL 3, 96.

${ }^{95}$ Por. tamże.
} 
sandrii Tymoteusz i Teofil ${ }^{96}$. Wydaje się, że w niektórych Kościołach poza Aleksandrią istniał zwyczaj poszczenia przed świętami Bożego Narodzenia ${ }^{97}$. Natomiast post był zabroniony przed świętem Zesłania Ducha Świętego, jak wynika z uchwał podjętych na synodzie w Septimunicum w Byzacenie (z roku $418)^{98}$. Konstytucje Apostolskie zalecały z kolei tygodniowy post po święcie Zesłania Ducha Swiętego:

„Po święcie Pięćdziesiątnicy świętujcie jeszcze przez tydzień, a potem przez tydzień zachowajcie post. Słusznie bowiem należy radować się z daru Bożego i pościć po odpoczynku" 99 .

Synod w Elwirze z 306 roku zalecał zaś w kanonie 23. dodatkowe posty co miesiąc, nie precyzując dni, w których miano by je praktykować. Co ciekawe wyłączone z nich były dwa miesiące: lipiec i sierpień, ,z powodu słabości niektórych"100, prawdopodobnie chodziło o wysokie temperatury powietrza, stanowiące już wystarczające utrudnienie życia.

Kanony wspominają też o poście eucharystycznym ${ }^{101}$, o którym nie wzmiankują Autorzy Historii kościelnych. Informacje na temat tej formy postu zawierają: 16. kanon Tymoteusza Aleksandryjskiego ${ }^{102}$, czy 19. i 28. kanon Hipolita $^{103}$. Wedle 4. kanonu synodu w Hipponie (393 rok):

„biskupi powinni o każdej porze sprawować święte nabożeństwa nie spożywając uprzednio posiłku, lecz powstrzymując się od jedzenia, co dotyczy również wiernych. Jeśli zaś przyjęliby pokarm, to wspominając pośmiertnie jakiegokolwiek świeckiego lub biskupa, niech uczczą go jedynie mową" ${ }^{104}$.

$28 .{ }^{105}$ i $41 .{ }^{106}$ kanon synodu w Kartaginie (397 rok) wskazywały, że nie trzeba postu eucharystycznego zachowywać jedynie w jeden dzień w roku, „gdy obchodzi się Wieczerzę Pańską", a więc w Wielki Czwartek.

Post połączony z modlitwą był cechą wyróżniającą chrześcijanina. Rufin z Akwilei, Teodoret z Cyru, Sokrates z Konstantynopola i Hermiasz Sozomen

\footnotetext{
${ }^{96}$ Por. tamże; Theophilus Alexandrinus can. 1, SCL 3, 98.

${ }^{97}$ Por. Timotheus Alexandrinus, Responsa canonica 23, SCL 3, 96.

${ }^{98}$ Por. Concilium Septimunicense (418) can. 215, SCL 4, 245.

${ }^{99}$ Constitutiones Apostolorum V 20 14, SCL 2, 134.

${ }^{100}$ Concilium Eliberitanum (306) can. 23, SCL 1, 53.

${ }^{101}$ Post eucharystyczny wprowadzono obowiązkowo w roku 318 w Afryce, a w całym Kościele stopniowo w wiekach IV-V; por. P. Hemperek, Eucharystyczny post, EK 4, 1281-1282.

${ }^{102}$ Por. Timotheus Alexandrinus, Responsa canonica 16, SCL 3, 94.

${ }^{103}$ Por. Canones Hippolyti can. 19 i 28, SCL 3, 190 i 194.

${ }^{104}$ Concilium Hipponense (393), SCL 4, 61. Por. Concilium Carthaginense (28 VIII 397, według Registri Ecclesiae Carthaginesis Excerpta) can. 47, SCL 4, 86; Concilium Carthaginense (397, według Collectio Hispana) can. 29, SCL 4, 96.

${ }^{105}$ Por. Concilium Carthaginense (397) Breviarium Hipponense can. 28, SCL 4, 79.

106 Por. Concilium Carthaginense (28 VIII 397, według Registri Ecclesiae Carthaginesis Excerpta) can. 41, SCL 4, 84.
} 
opisują przypadek pewnej branki, chrześcijanki, która dostała się do niewoli plemienia zamieszkującego na północ od Armenii, na terenie dzisiejszej Gruzji, a które historycy określali mianem Iberów. W ujęciu Teodoreta owa branka uważała post za wielki luksus ${ }^{107}$. Wedle Sokratesa miała ona prowadzić życie pobożnej chrześcijanki, zachowywać surową dyscyplinę w zakresie czystości, długie posty i oddawać się gorącej modlitwie ${ }^{108}$. W relacji Sozomena kobieta ta, mając upodobanie do postu i modlitwy ,w nocy i za dnia”, budzić miała zainteresowanie tubylców ${ }^{109}$. W zgodnym przekazie Rufina z Akwilei, Sokratesa z Konstantynopola i Hermiasza Sozomena kiedy za jej wstawienniczą modlitwą zostało uzdrowione dziecko, a potem małżonka samego władcy, nawrócił się cały lud, z królem na czele ${ }^{110}$. Podobnie niewiele brakowało w relacji Sokratesa, by nawrócił się na chrześcijaństwo król Persji Jezdegerd, kiedy to Marutas, biskup Martyropolis w Armenii, będący posłem cesarza rzymskiego oraz Ablaat, biskup Persji, a konkretnie Suzy, w cudowny sposób wypędzili z królewicza „dręczącego go demona”. Mieli tego dokonać, jak zauważył Sokrates, kiedy tylko „rozpoczęli posty i modły”"111.

Do postu zobowiązane było przede wszystkim duchowieństwo oraz dziewice i wdowy. Według 32. kanonu Hipolita kler miał pościć wedle własnego wyboru i sił, a biskup wtedy, kiedy wesprzeć go w tym umartwieniu mogli duchowni. Natomiast dziewice i wdowy winny pościć często i umartwienie to łączyć z modlitwą ${ }^{12}$. Kanony Atanazego 92. i 98. nakazywały dziewicom wypełniać post każdego dnia aż do wieczora. Zobowiązywano je do wyrzeczenia się mięsa, a nawet ryb oraz wina, $\mathrm{z}$ którego miały zrezygnować nawet w święta, w tym największe z nich - święto Wielkanocy, chyba że były cho$\mathrm{re}^{113}$. W soboty i niedziele miały jeść do syta raz dziennie w czasie wieczerzy. Spożywać miały pokarmy ubogich i pilnować, aby „brzuchów nie wypełniać chlebem". Bowiem w przekonaniu Atanazego, bez ciągłego postu dziewice nie byłyby w stanie zachować czystości. Te same nakazy obowiązywały mężczyzn zachowujących dziewictwo ${ }^{114}$. Wedle świadectwa Euzebiusza z Cezarei Orygenes, prowadząc filozoficzny, a więc ascetyczny tryb życia, ćwiczył się w postach, ograniczał czas snu i spał na gołej ziemi ${ }^{115}$.

\footnotetext{
${ }^{107}$ Por. Theodoretus, HE I 24, 1.

${ }^{108}$ Por. Socrates, HE I 20, 2.

${ }^{109}$ Por. Sozomenus, HE II 7, 1.

${ }^{110}$ Por. Rufinus, HE I 11; Socrates, HE I 20; Sozomenus, HE II 7.

${ }^{111}$ Socrates, HE VII 8, 19, GCS NF 1, 354, thum. Kazikowski, s. 506.

${ }^{112}$ Por. Canones Hippolyti can. 32, SCL 3, 195.

${ }^{113}$ Por. Canones Athanasii can. 98, SCL 3, 168. Według ówczesnych lekarzy słabe wino miało krzepić ciało (por. Hieronymus Stridonensis, Epistula 108, 21, 2, ed. I. Hilberg, CSEL 55, Vindobonae - Lipsiae 1914, 337, tłum. B. Degórski, w: Św. Hieronim, Listy do Eustochium, ŹM 33, Tyniec 2004, 253). Zob. M. Kokoszko, Smaki Konstantynopola, w: Konstantynopol Nowy Rzym. Miasto i ludzie w okresie wczesnobizantyńskim, red. M.J. Leszka - T. Wolińska, Warszawa 2011, 569.

${ }^{114}$ Por. Canones Athanasii can. 92, SCL 3, 166.

${ }^{115}$ Por. Eusebius, HE VI 3, 9.
} 
Jeśli chodzi o post mnichów, to wedle Hermiasza Sozomena z reguły nie brali oni do ust pokarmu przed zachodem słońca, a niektórzy z nich „pościli nawet przez trzy dni i dłużej" ${ }^{116}$. Ozdoba pustelni egipskich, wielki mnich Antoni, potrafił obejść się bez jedzenia dwa i więcej dni. Jak pisał Sozomen: „porą na śniadanie był dla niego moment, w którym zachodziło słońce" ${ }^{117}$. Sokrates z Konstantynopola przytacza przykład świętego mnicha Ammona i jego małżonki, którą ten namówił do ascezy. Para ta miała wstrzymywać się od spożywania pokarmów przez jeden, innym razem przez dwa dni, a bywało, że i dłużej ${ }^{118}$. Tak więc zwyczaje mnichów w tej materii były bardzo surowe, a zdarzali się wśród nich tacy, których wstrzemięźliwość od pokarmów trwała nawet więcej niż trzy dni i chodziło tu zapewne o kolejne dni tygodnia. Sokrates pisał nawet o ustawicznych postach, jakim oddawali się mnisi w pustelniach $^{119}$. Dla Efrema Syryjczyka, pochodzącego z Nisibis, wiele dni postu było czymś zwykłym, jak podaje Sozomen ${ }^{120}$, a według tego samego historyka Heliodor, mnich z pogranicza syryjsko-perskiego, pościł po siedem dni bez przerwy i tak tydzień po tygodniu ${ }^{121}$.

Jeśli natomiast chodzi o mnichów żyjących wedle reguły Pachomiusza, jaką ten miał otrzymać od anioła, to wprowadzała ona, wedle Sozomena, elastyczne zasady postępowania. Każdy z mnichów miał pościć, tak jak i pracować, wedle swoich możliwości - „na tyle, na ile go stać”. Jedynie ci, którzy odżywiali się lepiej, mieli wykonywać cięższe prace fizyczne. Lżejsze miały przypaść praktykującym „wstrzemięźliwość w korzystaniu z pokarmów”"122.

Z relacji Sozomena wynika, że wszyscy mnisi mieli przede wszystkim troszczyć się o duszę i to ,ze wszystkich sił i przygotowywać ją do rozstania się bez trudu ze sprawami tego ziemskiego bytowania"123. Życie poświęcać mieli modlitwom i postom oraz śpiewaniu hymnów ku czci Bożej ${ }^{124}$. Tak więc praktykowanie surowego postu połączonego z modlitwą było typowe dla mnichów.

${ }^{116}$ Sozomenus, HE I 12, 10, GCS NF 4, 26, thum. Kazikowski, s. 56. Na zwyczaj poszczenia przez cały rok przez żyjących samotnie w Palestynie ascetów zwracała uwagę Egeria (Itinerarium Egeriae 28, 3).

${ }^{117}$ Sozomenus, HE I 13, 4, GCS NF 4, 27, tłum. Kazikowski, s. 57.

${ }^{118}$ Por. Socrates, HE IV 23.

${ }^{119}$ Por. tamże VII 17.

${ }^{120}$ Por. Sozomenus, HE III 16.

${ }^{121}$ Por. tamże VI 34.

${ }^{122}$ Sozomenus, HE III 14, 10, GCS NF 4, 119, tłum. Kazikowski, s. 177. Wedłu Egerii (Itinerarium Egeriae 28, 3-4) żyjący w Palestynie apotaktycy (samotnicy), jeśli nie chcieli pościć przez wszystkie tygodnie Wielkiego Postu, spożywali wieczerzę piątego dnia, a więc w czwartek. Ci, dla których był to zwyczaj nazbyt surowy, podejmowali posty dwudniowe, a jeśli i to przekraczało ich możliwości jadali raz dziennie wieczorem. Umartwienia ascetów były więc zróżnicowane w zależności od stopnia ich wytrzymałości. Zob. Desprez, Początki monastycyzmu, t. 1, s. 315-316.

${ }^{123}$ Sozomenus, HE VI 34, 2, GCS NF 4, 290, thum. Kazikowski, s. 433-434.

${ }^{124}$ Por. tamże. 
Jak można przypuszczać, mnisi w podeszłym wieku byli zwolnieni z obowiązku postu. Sozomen dziwił się bowiem, że Elias, choć był już w podeszłym wieku, nadal pościł ${ }^{125}$. Wedle historyka jeden z mnichów, żyjących na pograniczu syryjsko-perskim, imieniem Alas do osiemdziesiątego roku życia miał nie poznać smaku chleba ${ }^{126}$. Można przypuszczać, że poznał go dopiero w tym wieku, a więc wówczas już tak ścisły post go nie obowiązywał. Wydaje się potwierdzać to 19. kanon synodu w Gangrze z roku 340, wedle którego jedynie warunki fizyczne mogły usprawiedliwić ascetę w zaniechaniu postu ${ }^{127}$.

Najczęściej post polegał na wstrzemięźliwości od spożywania wybranych pokarmów. I tak słynny mnich Antoni miał za pożywienie - jak pisał Sozomen - sam tylko chleb i sól, a za napój - wodę ${ }^{128}$, w relacji zaś Sokratesa z Konstantynopola święty mnich Ammon ze swoją małżonką mieli wstrzymywać się od konsumpcji „wina i oliwy, jedząc tylko suchy chleb" ${ }^{29}$. Podobnie Paweł, nowacjański biskup Konstantynopola, który wcześniej wiódł żywot mnicha, podziwiany przez Sokratesa, powstrzymywał się od pokarmu pochodzenia zwierzęcego oraz unikał wina i oliwy ${ }^{130}$. Miał się on wzorować na mnichach, praktykując ustawiczny, nieustanny post ( $\tau \grave{\eta} v \sigma v v \varepsilon \chi \hat{\eta} v \eta \sigma \tau \varepsilon i \alpha v)^{131}$. Sokrates pisał jednak także o zróżnicowaniu praktyk powstrzymywania się od pokarmów. Jedni rezygnowali ze spożywania wszelkiego mięsa ${ }^{132}$, inni czynili wyjątek dla ryb ${ }^{133}$, a jeszcze inni oprócz ryb nie gardzili także ptactwem, argumentując, ,że według Mojżesza i ono też pochodzi z wody"134. Byli i tacy, którzy nie jadali migdałów, orzechów, owoców i jaj, a również i tacy, którzy zadowalali się jedynie chlebem ${ }^{135} \mathrm{i}$ w końcu ci, którzy w trakcie postu nie spożywali żadnych posiłków ${ }^{136}$. W relacji Sozomena mnisi na ogół całkowicie powstrzymywali się od picia wina i spożywania żywności pochodzenia zwierzęcego: „Pokarmem był im chleb z solą i hizopem ${ }^{137}$, a za napój mieli wo-

\footnotetext{
${ }^{125}$ Por. tamże VI 28.

${ }^{126}$ Por. tamże VI 34.

${ }^{127}$ Por. Concilium Gangrense (340) can. 19, SCL 1, 128.

${ }^{128}$ Por. Sozomenus, HE I 13.

${ }^{129}$ Socrates, HE IV 23, 11, GCS NF 1, 250, thum. Kazikowski, s. 359.

${ }^{130}$ Por. tamże VII 17.

${ }^{131}$ Tamże VII 17, 4, GCS NF 1, 362.

${ }^{132}$ Por. Cyrillus Hierosolymitanus, Catecheses IV 27, PG 33, 489B, thum. W. Kania: Św. Cyryl Jerozolimski, Katechezy przedchrzcielne i mistagogiczne, BOK 14, Kraków 2000, 71; Basilius Caesariensis, De ieiunio 1, 10, PG 31, 181B, thum. T. Sinko, w: Bazyli Wielki, Wybór homilij i kazań, Kraków 1947, 165-166.

${ }^{133}$ Według Jana Chryzostoma (Ad populum antiochenum hom. 5, PG 49, 53) w Antiochii w czasie postu wyrzekano się mięsa, ale spożywano ryby.

${ }^{134}$ Por. Socrates, HE V 22, 37, GCS NF 1, 300, thum. Kazikowski 430.

${ }^{135}$ Por. Hieronymus Stridonensis, Epistula 52, 12, ŹMT 55, [wyd. łacińsko-polskie, tekst łac. oprac. H. Pietras, tłum. J. Czuj, wstęp i oprac. M. Ożóg], Kraków 2010, 22.

${ }^{136}$ Por. Socrates, HE V 22.

${ }^{137}$ Hizop - krzew stosowany powszechnie w krajach Basenu Morza Śródziemnego jako przyprawa.
} 
dę"138. Jednak niedopuszczalne było - wedle Sozomena - pogardzanie tymi, którzy spożywali mięsne pokarmy, co czynić miał Eustacjusz, biskup Sebasty w Armenii ${ }^{139}$. Takie postawy zdecydowanie potępiał synod w Gangrze ${ }^{140}$.

Postom towarzyszyła też często inna forma ascezy. Według Sokratesa mnichów w pustelniach cechowała wstrzemięźliwość w mowie ${ }^{141}$. Jeden z nich, niejaki Piotr, miał zwyczaj jadać spacerując, chcąc podkreślić w ten sposób podrzędny charakter tej czynności. Chciał się też pozbawić w ten sposób „przyjemności cielesnej, jaką sprawia jedzenie"142. Natomiast Heliodor łączył post z odmawianiem sobie snu i wytrwał w ten sposób „,bez zmrużenia powiek wiele nocy”143.

Kanony Apostolskie przewidywały karę złożenia z urzędu dla duchownych nieprzestrzegających postu w okresie Wielkiego Postu czy też w środy i piąt$\mathrm{ki}$, chyba że było to skutkiem choroby cielesnej ${ }^{144}$. Jak zatem widać, choroba zwalniała z obowiązku poszczenia. Podobnie rzecz przedstawiał 20. i 22. kanon Hipolita ${ }^{145}$, czy 10. odpowiedź prawna Tymoteusza, biskupa Aleksandrii, w której ten pozwolił ciężko chorym jeść i pić do woli, a nawet, jak to ujął, spożywać oliwę ${ }^{146}$. W odpowiedzi 8. zaś biskup Aleksandrii zezwolił kobietom, spodziewającym się dziecka około święta Paschy, na spożywanie dowolnych pokarmów i napojów, z winem włącznie. Wydaje się jednak, że owo złagodzenie wymagań nie dotyczyło automatycznie wszystkich kobiet ciężarnych, lecz jedynie tych, które czuły się już z racji swego stanu udręczone i słabe ${ }^{147}$.

20. kanon Hipolita usprawiedliwiał też tych, którzy nie podejmowali postu z powodu ,przeciwności lub potrzeby”"148. Te mało precyzyjne sformułowania miały obejmować, jak się wydaje, wszystkie sytuacje, które trudno było ująć w przepisie prawnym, a które jednak były dostatecznym wytłumaczeniem motywów rezygnacji ze wspomnianych umartwień. Prawdopodobnie opisany przez Hermiasza Sozomena przypadek Spirydona, kiedy ten przerwał post, kierując się prawem gościnności i obowiązkiem nakarmienia przybysza, można było zaliczyć do owych wyjątków, o których myślano, tworząc 20. kanon Hipolita $^{149}$.

Wedle Kanonów Apostolskich osoba świecka nieprzestrzegająca postu miała zostać wyłączona ze wspólnoty wiernych ${ }^{150}$. 19. kanon synodu w Gangrze

\footnotetext{
${ }^{138}$ Sozomenus, HE I 12, 10, GCS NF 4, 26, tłum. Kazikowski, s. 56.

${ }^{139}$ Por. Sozomenus, HE III 14.

${ }^{140}$ Por. Concilium Gangrense (ok. 340), Epistula synodica 10, SCL 1, 124.

${ }^{141}$ Por. Socrates, HE VII 17.

${ }^{142}$ Tamże IV 23, 20, GCS NF 1, 251, thum. Kazikowski, s. 360.

${ }^{143}$ Sozomenus, HE VI 34, 3, GCS NF 4, 290, thum. Kazikowski, s. 434.

${ }^{144}$ Por. Constitutiones Apostolorum VIII 47, 69 (= Canones Apostolorum 69), SCL 2, 289.

${ }^{145}$ Por. Canones Hippolyti 20 i 22, SCL 3, 190-191.

${ }^{146}$ Por. Timotheus Alexandrinus, Responsa canonica 10, SCL 3, 93.

${ }^{147}$ Por. tamże 8, SCL 3, 92.

${ }^{148}$ Canones Hippolyti can. 20, SCL 3, 190.

${ }_{149}$ Por. Sozomenus, HE I 11.

${ }^{150}$ Por. Constitutiones Apostolorum VIII 47, 69 (= Canones Apostolorum 69), SCL 2, 289.
} 
nakładał na ascetów anatemę, jeśliby powodowani pychą, uważając się za doskonałych, ,nie przestrzegali postów ustanowionych dla ogółu wiernych i zachowywanych przez Kościół"151. Według 12. kanonu synodu w Artsalth w Armenii (po 373 roku) każdy, kto łamie post w czasie Wielkiego Postu, zostanie potępiony wobec całej wspólnoty ${ }^{152}$. Ten sam synod (kanon 13.) przewidywał karę dodatkowego tygodniowego postu za spożywanie mięsa w środę lub w piątek $^{153}$. Zdarzały się jednak fałszywe oskarżenia o nieprzestrzeganie postu. Wedle 13. kanonu tegoż zgromadzenia ,jeśli prezbiter wykaże, że został fałszywie oskarżony o nieprzestrzeganie postu w środę i piątek, przełożony wspólnoty zabierze oskarżycielowi wołu i przekaże prezbiterowi" ${ }^{54}$. Wspomniane kanony świadczą zatem o pilnym obserwowaniu swoich członków przez wspólnotę chrześcijańską, która baczyła szczególnie na prezbiterów, pilnując, aby przestrzegali oni obowiązującego prawa kościelnego. Kary wyłączenia ze wspólnoty wiernych za nieprzestrzeganie postu dowodzą, że nie mógł być chrześcijaninem ten, kto unikał nakazanych w określonym czasie wyrzeczeń. Fałszywe oskarżenie prezbitera o niepodejmowanie obowiązkowych postów było na tyle poważnym wykroczeniem, że wymagało surowej kary i należytego zadośćuczynienia materialnego dla niesłusznie pomówionego.

Post połączony z modlitwą okazywał się skuteczną formą błagania Boga o pomoc. Jak sformułował to Bazyli Wielki: „,post odprowadza modlitwę do nieba, stając się dla niej niby skrzydłem w locie do góry" ${ }^{155}$. Euzebiusz z Cezarei, cytując fragment dzieła Ireneusza z Lyonu, Adversus haereses, wspominał o postach towarzyszących modlitwie błagalnej wspólnot chrześcijańskich ${ }^{156}$. W relacji Sokratesa, kiedy wywierano presję na Aleksandra, biskupa Konstantynopola, aby przyjął do wspólnoty Kościoła herezjarchę Ariusza i jego zwolenników, grożąc mu złożeniem z urzędu, ten „odrzucił dialektyczną mądrość i schronił się pod opiekę Bożą. Jednocześnie ciągle praktykował posty i nie pomijał żadnego rodzaju modlitwy" 157 . W przekonaniu historyka powodowała nim przede wszystkim troska o Kościół i prawowierną naukę. Przez wiele dni i nocy zamknięty sam w kościele Pokoju Bożego ${ }^{158}$, gdyż nie chciał zwracać na siebie niczyjej uwagi, zanosił modły do Boga. Prosił zaś o swego rodzaju sąd Boży, o to, by sam Bóg wskazał, kto w prowadzonym sporze doktrynalnym ma rację. Niespodziewana hańbiąca śmierć Ariusza w latrynie miała być odpowiedzią Boga i karą dla herezjarchy za bezbożność. Tak więc postawa

${ }^{151}$ Concilium Gangrense (ok. 340) can. 19, SCL 1, 128.

${ }^{152}$ Por. Concilium in Artsalth (po 373 roku) can. 12, SCL 1, 279.

${ }^{153}$ Por. tamże can. 13, SCL 1, 279.

154 Tamże.

${ }^{155}$ Basilius Caesariensis, De ieiunio I 7, PG 31, 173C, thum. Sinko, s. 161.

${ }^{156}$ Por. Eusebius, HE V 7, 2.

${ }^{157}$ Socrates, HE I 37, 6, GCS NF 1, 88, thum. Kazikowski, s. 147. Sozomen (HE II 29, 3) pisał jedynie o gorącej modlitwie Aleksandra, który, padłszy u stóp ołtarza, leżał przez całą noc, zanosząc prośby do Boga.

${ }^{158}$ Sozomen (HE II 29, 3) nie precyzował o jaki kościół chodziło. 
Aleksandra, pełna pokory i zawierzenia Bogu, czego wyrazem był post połączony z korną modlitwą, doczekała się nagrody.

Didache kierowała do chrześcijan następującą zachętę:

„módlcie się za waszych nieprzyjaciół, pośćcie za waszych prześladowców (por. Mt 5, 44; Łk 6, 28)" ${ }^{\prime 159}$.

W tym duchu, w relacji Sozomena, Didymus, nauczyciel chrześcijańskiej mądrości przebywający w Aleksandrii, przeżywając odstępstwo cesarza Juliana od Kościoła, „zmartwiony, że cesarz ciężko zgrzeszył przeciw wierze”, rozpoczął ścisły post połączony z modlitwą w intencji władcy, ,jak i w intencji Kościoła, który doznał pogardy". Sozomen podkreślał, że nawet z nadejściem nocy Didymus nie przyjął żadnego pokarmu. W czasie snu zaś jeźdźcy na białych rumakach mieli go powiadomić o śmierci cesarza Juliana i polecić, by powiadomił o niej biskupa Aleksandrii Atanazego. Polecili mu też powstać i spożyć posiłek. Modlitwa wsparta ścisłym postem okazała się zatem i w tym wypadku bardzo skuteczna ${ }^{160}$.

Post był również dobrym sposobem, by zaradzić przykrym zjawiskom. W relacji Sokratesa, kiedy jednego z mnichów ,niepokoiły nocą widziadła”, drugi uwolnił go od tych przykrości, ,poleciwszy mu, by usługiwał chorym, a jednocześnie pościł"'161. W przekonaniu owego mnicha nic tak skutecznie nie usuwało podobnych dolegliwości, jak okazywanie współczucia ${ }^{162}$. Trzeba jednak zauważyć, że samo współczucie nie wystarczyło. Niezbędny jeszcze okazał się post.

Praktykę postu stosowano nadal rutynowo wobec katechumenów mających przyjąć chrzest. Sokrates podaje, że kiedy Burgundowie zorientowali się, iż „Bóg Rzymian potężnie wspiera tych, którzy Go wielbią”, postanowili przejść na chrześcijaństwo. Poprosili zatem o chrzest jednego z biskupów galijskich. Ten zaś wyznaczył im ,siedem dni postu i wprowadziwszy w zasady wiary, ósmego dnia ich ochrzcił"163. Prawdopodobnie nauczał ich zatem w czasie, gdy pościli. Post przed chrztem zalecała Didache: „przed chrztem powinni pościć i chrzczony i udzielający chrztu, a także inni, jeśli mogą" 29. kanon obowiązujący w Kościele w Irlandii (ustanowiony w latach 456465) nakazywał chrzest dopiero po 40 dniach postu ${ }^{165}$. 23. kanon obowiązujący w Galii (ok. 475-485) dopuszczał do chrztu sprawdzonych długą wstrzemięźliwością od wina i mięsa ${ }^{166}$.

${ }^{159}$ Didache I 3, ed. W. Rordorf, SCh 248, Paris 1978, 142-144, thum. A. Świderkówna, w: Pierwsi świadkowie. Pisma Ojców Apostolskich, BOK 10, Kraków 1998, 33.

${ }^{160}$ Por. Sozomenus, HE VI 2, 6-8.

${ }^{161}$ Socrates, HE IV 23, 42, GCS NF 1, 253, thum. Kazikowski, s. 362.

${ }^{162}$ Por. tamże.

${ }^{163}$ Tamże VII 30, 4, GCS NF 1, 378, tłum. Kazikowski, s. 539.

${ }_{164}$ Didache VII 4, SCh 248, 172, BOK 10, 36.

${ }^{165}$ Por. Synodus S. Patrici in Hibernia (456) can. 29, ŹMT 62, [wyd. łacińsko-polskie, układ i opracowanie A. Baron - H. Pietras], Kraków 2011 = SCL 6, 192.

${ }^{166}$ Por. Statuta ecclesiae antiqua can. 23, SCL 6, 264. 
Podobnie rutynowo aplikowano post pokutującym, jak było w przypadku pewnej niewiasty ze znakomitego rodu, która otrzymała w ramach pokuty zalecenie postu i modlitwy w kościele. Spełniając ów obowiązek w świątyni, miała zostać w niej zhańbiona przez diakona, co wstrząsnęło całą wspólnotą wiernych w Konstantynopolu ${ }^{167}$. Podobnie w kościele rzymskim, co podkreślał Sozomen, nakładano na pokutujących różne formy wyrzeczeń. Były nimi przede wszystkim post czy wstrzemięźliwości od określonych pokarmów, ale także, jak świadczy przekaz historyka, unikanie kąpieli ${ }^{168}$.

Mimo surowego postu mnichów nie opuszczało poczucie humoru, jak świadczy opowiadanie Sozomena na temat Efrema Syryjczyka z Nisibis, mimo że ten początkowo, zanim został mnichem, miał problem z panowaniem nad gniewem. W relacji historyka, kiedy po wielu dniach postu sługa zbił naczynie z posiłkiem przeznaczonym dla Efrema, ten miał powiedzieć do zalęknionego winowajcy: „Nie martw się! Skoro przekąska nie przyszła do nas, chodźmy więc my do przekąski!" 169.

Bywało, że surowy post prowadził do uszczerbku na zdrowiu. Na przykład w relacji Sozomena niejakiemu „Batthaiosowi na skutek nadmiernego obywania się bez jedzenia zaczęły z próchniejących zębów wypełzać robaki”'170, a Makary z Aleksandrii wychudł tak niesłychanie, że przestała mu rosnąć broda ${ }^{171}$.

$$
* * *
$$

Podsumowując, stwierdzić należy, że Historie kościelne z IV i V wieku dają świadectwo praktyce postu podejmowanej przez ówczesnych chrześcijan. $Z$ relacji historyków wynika, że post połączony z modlitwą był cechą wyróżniającą pobożność chrześcijańską. Zasadniczym zaś, od IV wieku, czasem praktykowania wstrzemięźliwości pokarmowej był okres czterdziestodniowego postu przed świętem Wielkanocy oraz dwa dni w tygodniu - środa i piątek, co ściśle odpowiadało ówczesnej regulacji prawnej. Jednak jeszcze w połowie $\mathrm{V}$ wieku w poszczególnych Kościołach nie było jednomyślności ani co do długości trwania postu przed Wielkanocą, ani co do jego formy. Praktykę postu stosowano również rutynowo wobec katechumenów i ich Kościołów lokalnych przed sakramentem chrztu czy wobec pokutujących, przede wszystkim jednak oddawali się jej asceci, a niezwykle surową tego rodzaju praktykę uprawiali mnisi.

\footnotetext{
${ }^{167}$ Por. Sozomenus, HE VI 16.

168 Por. tamże.

169 Tamże III 16, 10, GCS NF 4, 129, tłum. Kazikowski, s. 191.

${ }^{170}$ Tamże VI 34, 3, GCS NF 4, 290, tłum. Kazikowski, s. 434.

${ }^{171}$ Por. tamże III 14.
} 


\title{
THE PRACTICE OF FASTING \\ IN THE LIGHT OF THE ECCLESIASTICAL HISTORIOGRAPHY \\ OF THE IV-V CENTURIES
}

\begin{abstract}
(Summary)
The ecclesiastical histories of the fourth and the fifth centuries confirm the fasting as a practice popularly observed by the Christians of that time. From the account of the historians one can conclude that fasting combined with prayer was a distinctive feature of Christian piety. From the fourth century the principal practice of abstention from food included the concept of a forty-day fasting period before Easter, i.e. Lent, and additionally the fast practiced two days every week throughout the year, namely each Wednesday and Friday, while the scheme is considered to have its roots in the regulations promoted by the Church authorities of the period. Nonetheless, by the middle of the fifth century the individual churches of the West and the East had not arrived at an unanimous agreement on the length of Lent neither on its form. Moreover, the practice of fasting was also introduced as obligatory for the catechumens before baptism and for the local church communities they represented. Additionally, fasting was a must for those repenting their sins. First and foremost, however, a very strict practice of food abstention was observed by the monks of the period.
\end{abstract}

Słowa kluczowe: Post, Wielki Post, historiografia kościelna, kanony kościelne, monastycyzm, historia Kościoła IV-V wiek.

Keywords: fasting, Lent, ecclesiastical historiography, canons of the Church, monasticism, history of the Church of the IV-V centuries. 